Disponível em

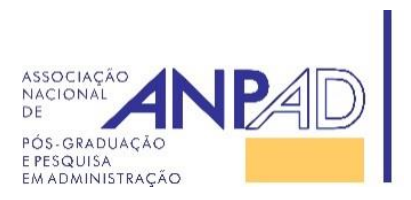

http://www.anpad.org.br/rac

RAC, Rio de Janeiro, v. 21, n. 6, art. 1,

pp. 743-763, Novembro/Dezembro, 2017

http://dx.doi.org/10.1590/1982-7849rac2017160166

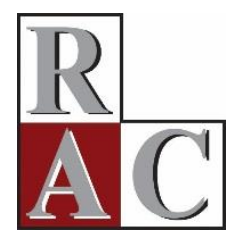

$(\mathrm{cc}) \mathrm{EY}$

\title{
Plural Forms of Governance at Central Supply Markets
}

Susan Yuko Higashi ${ }^{1}$

Mayra Batista Bitencourt Fagundes ${ }^{1}$ Silvia Morales de Queiroz Caleman ${ }^{1}$

Leandro Sauer ${ }^{1}$

Maria Sylvia Saes ${ }^{2}$

Universidade Federal de Mato Grosso do Sul ${ }^{1}$ Universidade de São Paulo ${ }^{2}$ 


\title{
Resumo
}

O trabalho consiste em analisar os aspectos transacionais da relação entre produtores e permissionários da CeasaMS. Para atingir o objetivo proposto, houve a aplicação, juntamente aos permissionários da Ceasa-MS, de 78 questionários semiestruturados. Os questionários aplicados tiveram como arcabouço teórico a ECT, em conjunto com a teoria das formas plurais. Analisando as dimensões da transação entre os permissionários da Ceasa-MS e seus fornecedores, percebemos que o ativo estudado possui: (a) uma especificidade média; (b) a incerteza das transações é alta; (c) e as transações ocorrem de forma recorrente. A teoria da ECT prediz que essas transações devem ocorrer de forma híbrida, porém verificou-se que, além do uso das formas híbridas, há o uso da integração vertical e das formas plurais, sendo esta a combinação entre as formas híbridas e a integração vertical. A presença das formas plurais na Ceasa é explicada pela ambiguidade sobre a estrutura de governança mais adequada de organização e pela complexidade no monitoramento das transações. Dentre os arranjos organizacionais, foi possível verificar que o uso das formas plurais reduz o custo de transação para o permissionário da Ceasa-MS, por representar a combinação entre os pontos positivos das formas híbridas e os da integração vertical, anulando, assim, seus pontos fracos.

Palavras-chave: Ceasa-MS; economia dos custos de transação; formas plurais.

\begin{abstract}
This study consists of analyzing the transactional relationship between farmers and authorized contractors at Ceasa-MS. In order to reach the objective proposed by the study, 78 semi-structured questionnaires were distributed among the contractors at Ceasa-MS. The questionnaires had as a theoretical framework the TCE in conjunction with the plural forms theory. Analyzing the transaction dimensions between the farmers and contractors at Ceasa-MS, we perceived that the assets studied possess: (a) average specificity; (b) uncertainty of the transactions is high; (c) and transactions occur on a recurring basis. Keeping such dimensions in mind, the TCE theory foresees that those transactions should happen in hybrid form, however the contractors served themselves with vertical integration and plural forms, the latter being the combination of hybrid forms and vertical integration. The presence of plural forms is explained by the ambiguity in the governing structure and the complexity in the way transactions are monitored. We verified that the use of plural forms or the simultaneous use of vertical integration with hybrid forms within all organizational arrangements, to reduce the transaction cost for the contractors as the combined positive aspects of the hybrid forms and vertical integration nullify their weak points.
\end{abstract}

Key words: Ceasa-MS; transaction cost economics; plural forms. 


\section{Introduction}

The article is important because it studies the transactions that occur in Central Market Supply in the Brazilian state of Mato Grosso do Sul (Centrais de Abastecimento de Mato Grosso do Sul [CEASAMS]) through two theoretical lenses: Transaction Cost Economics (TCE) and Plural Forms of governance. This approach is significant as it allows for a focus on the transactions between contractors and their suppliers, and the evaluation of which organizational form denotes superior efficiency.

Along these lines, the present study inquire is: What is the most efficient organizational form that enables transaction costs reduction between farmers and Ceasa-MS contractors?

Transaction Costs Economics, a branch of the New Institutional Economics (NIE), represents a more realistic theory about human agents due to its inclusion of limited rationality and opportunistic behavior (Williamson, 1985). Coase was a pioneer in organizational studies in 1937 with a more refined eye towards reality. The central issue in organizations is related to the constant intention of minimizing transaction costs, which is a vision that TCE endorses (Williamson, 1996).

According to Coase (1937), transactions tend to occur in two distinct manners: either market or hierarchy. Williamson (2002) has continued Coase's work by proposing that transactions could occur by the market, through the hierarchy, or even by hybrid forms. So the optimal governance structure selection is influenced by three attributes: asset specificity, frequency and uncertainty.

Several empirical studies have demonstrated the significance of TCE in Brazilian agribusiness. Lourenzani and Silva (2004) have analyzed transactions in the distribution of vegetables in Ceagesp Company of Warehouse and General Storage of São Paulo. The authors verified that the transactions between farmers and contractors have occurred most commonly via market structure. However, they have also verified transactions through informal or formal contracts. Other empirical studies have also utilized TCE as a tool for analysis, such as Silvia and Saes' (2005) study about transactions in poultry farming and Mondelli and Zylbersztajn's (2008) research on contractual arrangements in the Uruguayan beef industry.

However, recent studies have been developed to analyze transactions using other theoretical perspectives besides the TCE. Researchers have investigated the use of plural forms, defined by Bradach and Eccles (1989) as arrangements in which different mechanisms are employed concomitantly by the same firm and for the same function.

Feltre and Paulillo (2013) who have studied plural forms implementation in the sugar cane sector in western São Paulo have confirmed this logical lineage. The authors have verified that of the ten analyzed sugar cane mills, only one doesn't use plural forms in the purchase of inputs. Plural forms utilization by sugar cane mills is related to the outsized fixed capital investment that must be made. Moreover, the use of the plural forms ensures greater security of supply in long term.

Silveira, Carrer, Carvalho, Foscaches and Saes (2014) have analyzed plural forms existence in transactions between slaughterhouses and cattle ranchers. The authors verified, only one of three industries operated plural forms, with the main motive being a company's strategic behavior. The use of plural forms has reduced informational asymmetry as well as ensured advantages in scale and bargaining power.

Foscaches, Saes and Vacari (2016) analyzed the factors that lead to plural forms use in Brazilian coffee roasting and grinding for inputs acquisition. The authors studied 120 companies, of which 20 utilize plural forms.

The objective of this study is to analyze the transaction aspects in the relationships between farmers and contractors at Ceasa-MS. Ceasa was selected as the study object due to the absence of plural forms studies in this sector, since previous studies have been exclusively focusing on the analysis of 
Ceasa according to Williamson's theory. Despite the importance Ceasa has for the food chain, the sector is scarcely explored in Brazilian literature.

This work contributes to plural forms use, demonstrating that their practice reduces the companies' transaction costs, when compared to utilization of a single governance form. Therefore, plural forms use represents a more efficient strategy than when the term was proposed by Williamson theory. In addition, it is noticeable that when companies are newer and have smaller suppliers, there is a pronounced tendency to use plural forms.

\section{Theoretical Framework}

\section{New institutional economics (NIE)}

Coase (1937) stated that the negotiation costs and contracts elaboration for each transaction must be taken into consideration when measuring companies' overall costs. Williamson (2000) argue that limited rationalization and opportunistic behavior of economic agents, associated with transaction attributes, define the governance structure.

\section{Transaction costs economics (TCE)}

According to Coase, companies must decide whether to buy raw materials or produce their own. He argues that this decision is what differentiates companies, regarding their size, scopes and structures (Coase, 1937). Several authors refer to TCE as a more realistic treatment of firms, as an efficient administrative instrument that assists in the exchange between economic agents (Carter \& Hodgson, 2006; Leiblein, 2003; Macher \& Richman, 2008; Speklé, 2001; Williamson, 2002).

Economic agents are considered rational, but present frequent limitations. Regarding this rationalization, it is mandatory that companies consider their costs with planning, adaptation and monitoring transactions. Limited rationality explains the choice between governance structure and incomplete supporting contracts. These, when added to opportunism, may generate concerns in complying with such contracts. Hence it is essential that the contracts contain safeguard clauses to counterbalance their incompleteness (Foss, 2003; Foss \& Weber, 2016; Williamson, 1985, 2002).

Since opportunism can be ex post or ex ante, a transaction can be defined as the capacity to release information in an incomplete, distorted or even obscure manner with a clear intention to deceive. Thus, a transaction may often become the cause behind information asymmetry. This can be considered the origin of information asymmetry. The cultural perspectives of individualism and collectivism can influence propensity for opportunistic behavior (Chen, Peng, \& Saparito, 2002; Williamson, 1985).

Williamson (1985) states that three characteristics must be considered in order to choose the best governance structure. In other words, to mitigate the transaction costs, three transactional aspects must be taken into account.

The first feature is asset specificity, the most important transaction dimension that must be considered when choosing the right governing structure due to its tendency of associating more specific assets with larger bilateral dependency. This implicates an option for organizational forms with additional guarantees. In other words, the more specific the asset, the greater the need for specific investments in physical and/or human assets. Asset specificity presents significant importance whether associated with limited rationality, opportunistic behavior or uncertainty. Moreover, a specific asset increases the need for knowledge of the partners involved in the transaction. Therefore, the transaction passes through the market, occurring via contracts or internally within the firm (Poppo \& Zenger, 2002; Williamson, 1985). 
According to Williamson, uncertainty is counted as the other dimension as this reflects a company's ability to adapt itself to uncertain events. Nonetheless, this might also be linked with limited rationality since it leads to incomplete contracts, which increases contractual breaches. This increases opportunistic behavior risk, which finally culminates in elevated transaction costs (Williamson, 1985).

Frequency is how often the transactions occur. Companies display all kinds of transactions, some do not get repeated, while others can become recurring (Williamson, 2002).

These three features influence the structures through which the transactions occur. Williamson (2002) listed three governance structures in which the relationship between clients and suppliers could occur: market, hierarchy and hybrid forms.

Market structure refers to the company's choice of buying their raw materials for production. In this governance structure, companies expose themselves to uncertainties, such as price oscillation and raw material availability for their final products. The market tends to work satisfactorily until the emergence of the need to carry out the contracts (Williamson, 2002, 2008).

The hierarchy structure is marked by strong cooperation and mutual dependency among the involved parties. In this context, the incentives intensity is vulnerable due to bureaucratic costs. Numerous authors consider this as the governance structure that reduces transaction opportunism by fiat power (David \& Han, 2004; Foss \& Weber, 2016; Williamson, 1996).

The hybrid form occurs when the parties share certain property rights of an asset, however, they still exhibit control of key assets ownership rights for their operation. Exploiting hybrid forms, the companies try to uphold their autonomy and yet guarantee market incentives. Contracts aim to reduce the uncertainty and risks inherent in transactions that may result from both opportunistic behaviors and agents' limited rationality (Ménard, 2004; Williamson, 2002).

Therefore, the economic reasons that lead to the selection of an enhanced governance structure, in which the transactions can be performed, have worked as the foundation for analysis of the transactions between farmers and contractors at Ceasa-MS. This has also contributed to reveal whether such transactions really occurred as proposed by TCE.

\section{Plural forms}

The importance of TCE in explaining companies' limits is undeniable. However, its logic doesn't present any feasible reason to clarify the existence of simultaneous supply. As stated by Williamson, the selection for an optimum governing structure consists of an inconspicuous choice among the three alternatives: the market, hierarchy and hybrid form. Each choice includes its own attributes and peculiarities that end up minimized, depending on the characteristics-associated characteristics (Parmigiani, 2007).

Consequently, the hypothesis of efficient alignment within TCE theory amounts to a single governance structure selected as the optimum choice for the company. On that account, the three structures are alternative forms. In addition, Williamson's point of view about the alignment does not explain the possible effects resulting from combinations among the described forms (Parmigiani, 2007).

In fact, organizations can be considered extremely complex structures, which emphasizes that the three structures proposed by Williamson should not be contemplated as the exclusive elements involved in organizational forms selection (Bradach \& Eccles, 1989; Cliquet \& Croizean, 2002). Mols (2010) agrees with this line of thought, stating that despite the significant theoretical importance of Williamson's study, the explanation about why companies display a simultaneous combination of governance structures is still absent in his studies.

Intending to understand the simultaneous use of different structures for similar transactions, a plural form concept was created. This can be understood as a complex of organizational arrangements 
utilized for a class of transactions that are connected to the same activity, within the same institutional and competitive environment. It is noteworthy that transactions can be denominated as plural forms only when the purchased inputs are similar (Krzeminska, Hoetker, \& Mellewigt, 2013; Ménard, 2013).

Bradach and Eccles (1989) studied the three mechanisms for controlling transactions: price, authority and trust. In the other words, market, hierarchy and hybrid forms. In contrast to Williamson's theory (2002), which understands market, hierarchy and hybrid forms as distinct control mechanisms, Bradach and Eccles (1989) have treated price, authority and trust as independent factors that may be combined.

Mols (2010) have argued that plural forms are significant due to their potential to reduce both information asymmetry, and the negative effects of technology uncertainty as well as provide multiple sources for the new technology. Thus, companies have a superior chance of being encased by the most feasible technology. In addition, plural forms combine internal and external resources, reducing uncertainty of product volume, facilitating adaptation in relation to demand.

Ménard (2013) created a model based on Williamson's model that explains the three possible determining factors leading to the use of plural forms: the ability to deal with ambiguity, the complexity level in monitoring transactions, and strategic behavior. These three factors have led the author to suggest three propositions: ambiguity is intertwined with the difficulty in measuring degree of asset specificity; monitoring complexity related from the difficulty of monitoring the transactions, due to the uncertainty about the most efficient monitoring manner; and strategic behavior dependency on the strategies of how to organize a specific transaction (Ménard, 2013).

Therefore, the economics' agents diversify their governance structure, using two or more structures proposed by Williamson - market, hybrid, and hierarchy. Nonetheless, to perform this choice, agents must consider not merely the specificity asset, but also ambiguity, monitoring complexity and strategic behavior (Ménard, 2013).

Consequently, plural forms exist for companies to guarantee safety and coordination, regarding suppliers, thus avoiding an interruption in quality and quantity of products. Moreover, as proposed by Williamson (2002) the search for solutions would be constantly focused on cost reduction (Ménard, 2013).

Plural forms use theory was necessary due to the significant alterations over time in the scenario in which transactions within the agribusiness chain are continuously occurring. With this, the governance structure will hardly occur in a singular way - use or market, or hierarchy, or hybrid forms - that is, the transactions within agribusiness chain could simultaneously occur through one or more governance structures. Accordingly, this study has sought to understand how the transactions were occurring in Ceasa-MS.

\section{Methodological Procedures}

A case study was carried out intending to respond to the question raised and understand the dynamics present in each scenario. Case studies are characterized by in-depth analysis of one or a few objects, enabling extensive and detailed knowledge. A case study combines several data collection methods, such as questionnaires, archive review, interviews and observations. These works can be qualitative, quantitative or mixed method (Eisenhardt, 1989; Yin, 1981). Therefore, the case studied involved the transactions between farmers and contractors of Ceasa-MS. This research utilized qualitative methods, but quantitative techniques were also applied for an in-depth study.

A semi-structured questionnaire was applied to the contractors working at Ceasa-MS. This questionnaire was created based on Transaction Costs Economics theory, elaborated from Williamson's $(1985,1996,2002,2008)$ work. Thus, this methodology took into account the transactional aspects and 
certain dimensions, such as asset specificity, uncertainty and frequency, which together influence companies and their choice of a governance structure, e.g. market, vertical integration and hierarchy. Table 1 offers an association between TCE theory and the applied questionnaire.

Table 1

\section{TCE and the Questionnaire}

\begin{tabular}{|c|c|}
\hline NIE & Questions \\
\hline Transactional Aspects & $\begin{array}{l}\text { - Are you also a farmer? If so, do you buy from other farmers? } \\
\text { - Is the product you buy the same produced in your farm? If so, why do you buy it? } \\
\text { - What is the product? } \\
\text { - What percentage do you buy of this product? } \\
\text { - Do you prefer to buy products from local farmers in the state of MS? Why? } \\
\text { - Do you take into consideration the farmer's reputation when conducting new } \\
\text { business? } \\
\text { - The farmers you are doing business with are old (partners) - Have you been } \\
\text { business associates for more than a year? } \\
\text { - Is your relationship with the farmers conducted by mediators? } \\
\text { - Are your transactions conducted by means of formal contracts? Why? } \\
\text { - Are your transactions conducted by means of informal contracts? Why? } \\
\text { - Is the price paid for the products the same as the market? }\end{array}$ \\
\hline Assets specificity & $\begin{array}{l}\text { - Since your product is perishable, are you able to wholesale before it spoils? } \\
\text { - Has this company invested in technology in the last } 5 \text { years? Which type of } \\
\text { technology? } \\
\text { - Is there a product loss throughout transportation? } \\
\text { - Is there a product loss during storage? }\end{array}$ \\
\hline Frequency & - How often are transactions negotiated? \\
\hline Uncertainty & $\begin{array}{l}\text { - Which aspects influence your choice of farmers with whom you will perform } \\
\text { transactions? } \\
\text { - Can your supplier provide you with the same required amount of product } \\
\text { regularly? } \\
\text { - Can your supplier provide you with the same required quality of product } \\
\text { regularly? } \\
\text { - Are there any instances when transactions are unfulfilled by the farmers? Why do } \\
\text { you think this happens? } \\
\text { - Are there any penalties when a transaction is not completed? } \\
\text { - Can the farmers adapt themselves to unexpected changes in product orders? }\end{array}$ \\
\hline
\end{tabular}

Note. Source: Created by the author of this study.

Table 2 connects the applied questionnaire with three factors that lead to the use of plural forms, which, according to Ménard (2013), are ambiguity, complexity and strategic position. 
Table 2

\section{Plural Forms Theory and Questions}

\begin{tabular}{ll}
\hline Factors & Questions \\
\hline Ambiguity & - How many producers do you do business with? \\
& - Since your product is perishable, are you able to wholesale before it spoils? \\
& - Are there any instances when the transactions are unfulfilled by the farmers? \\
\hline Complexity & - How long have you worked in Ceasa-MS? \\
& - Can your supplier provide the same required amount of product regularly? \\
& - Can your supplier provide the same required quality of product regularly? \\
& - How often are transactions negotiated? \\
\hline Strategic Position & - Is the price paid for the products the same as the market? \\
\hline
\end{tabular}

Note. Source: Created by the author of this study.

According to the CEASA-MS website (n.d.), this market is divided in two classes: Box and Stone. The 47 contractors belonging to the Box group are known for trading large volumes in daily sales. The 180 Stone group contractors are responsible for a small volume of sales.

We randomly applied 28 questionnaires to Box group contractors and 50 to those belonging to the Stone group. The questionnaire application was performed individually with either contractors or managers of the establishments. Each application lasted approximately 30 minutes during morning, when the commercialization is staged, which represents the unique period in which contractors are in Ceasa. In approaching the interviewees, we first asked whether they would like to participate. Twentyfive percent refused to respond, however, the majority agreed to respond to the questionnaire.

The questionnaire application was divided into two parts: the first part intended to characterize the contractor's profile. During this phase, the following variables were considered: how long a person had been a contractor; which products they have traded; how many employees they had; whether employee turnover was elevated; how many farmers did the contractors do business with; where (which states) did the purchased products come from; and how were the calculations for product purchases performed.

After identifying the contractor's profile, the second part of the questionnaire addressed issues between farmer and contractor transactions. In this phase the transaction dimension, including asset specificity, frequency and uncertainty were discussed with the intent of revealing the governance structure controlling the transactions between the contractors and the farmers.

The interviewer asked verbal questions in order to facilitate understanding the questions due to the possibility of solving in an indistinct manner any doubt that the interviewee could had about any question. Moreover, the interviewer completed the questionnaire, avoiding the possibility of an interviewee skipping a question or answering without reading them, thus preventing possible filling errors and response biases. In addition, we made it clear to the interviewees that the survey would not reveal their name or their company, and that there would be no answers considered better or worse, and therefore they could respond as honestly as possible. Such precautions were taken to avoid problems with common method bias

Despite the ease in applying a questionnaire, there are some disadvantages pointed out by Van Gelder, Bretveld and Roeleveld (2010), including depleted participation rates. These, according to the authors, are decreasing by about $1 \%$ per year in certain fields of science, denoting a decline in people's willingness to respond to questionnaires. 
In July, 2014, a pre-test was conducted at Ceasa-MS, with 40 questionnaires applied to the contractors. In January, 2015, the questionnaires were then applied for final and conclusive data collection.

The analysis of the relationship between these two groups at Ceasa-MS was performed considering that agri-food was, in general, the type of asset involved in fulfilled transactions.

From the questionnaire application we were able to verify which governance structure the contractors use. Moreover, it was feasible to notice that some contractors utilize plural forms to acquire their inputs.

\section{Logit model}

Intending to evaluate and quantify which studied variables either influence or not affect the use of plural governance forms in Ceasa-MS, we chose to use the Logit Model due to its capability of identify the likelihood of a certain event happening (Greene, 2012). Regarding the purposes of this research, the analyzed event was the contractor likelihood to use or not use plural forms of governance for inputs purchase. The Logit Model encompasses a flexibility in relation to both normality assumption and the equal covariance-variance matrices in the groups (Greene, 2012; Hair, Anderson, Tatham, \& Black, 2009).

Inquiring whether contractors were producers and yet bought the same product from other producers gave insight into how contractors purchased their inputs. If the answer was yes to both questions, the supply was considered to be through a plural form, and when not, the contractor was seen to be a simple form user, as proposed by Williamson. Therefore, the analyzed variables were:

. Dependent variable: $0=$ no plural form use; $1=$ use of plural forms;

. Independent variables: the measurement form and expected signal are addressed in Table 3.

Table 3

Variables, Measurement and Expected Signal

\begin{tabular}{|c|c|c|}
\hline Variable & Measurement & Expected signal \\
\hline Number of suppliers & $\begin{array}{l}1=1 \text { supplier; } 2=2 \text { suppliers; } 3=3 \\
\text { suppliers; } 4=4 \text { suppliers; } 5=5 \text { or } \\
\text { more suppliers }\end{array}$ & $\begin{array}{l}+ \text { (positive), when the number of } \\
\text { suppliers is more elevated, the } \\
\text { greater the likelihood of plural forms } \\
\text { use. }\end{array}$ \\
\hline $\begin{array}{l}\text { Sell every product without } \\
\text { deterioration: }\end{array}$ & $0=\mathrm{No} ; 1=\mathrm{Yes}$ & $\begin{array}{l}\text { - (negative), when the sales are } \\
\text { preeminent, the greater the } \\
\text { likelihood of plural forms uses. }\end{array}$ \\
\hline Transaction break & $0=\mathrm{No} ; 1=\mathrm{Yes}$ & $\begin{array}{l}+ \text { (positive), when the likelihood of } \\
\text { transaction break is more abundant, } \\
\text { the greater the likelihood of plural } \\
\text { forms use. }\end{array}$ \\
\hline Operation Time & $\begin{array}{l}1=\text { at least } 5 \text { years; } 2=6 \text { to } 10 \text { years; } \\
3=11 \text { to } 15 \text { years; } 4=16 \text { to } 20 \text { years; } \\
5=\text { more than } 20 \text { years }\end{array}$ & $\begin{array}{l}\text { - (negative) when the company is } \\
\text { younger, there would be more } \\
\text { likelihood of plural forms use. }\end{array}$ \\
\hline Supply quality & $0=\mathrm{No} ; 1=\mathrm{Yes}$ & $\begin{array}{l}\text { - (negative) when the supply quality } \\
\text { is lower, the greater the likelihood of } \\
\text { plural forms use. }\end{array}$ \\
\hline
\end{tabular}


Table 3 (continued)

\begin{tabular}{lll}
\hline Variable & Measurement & Expected signal \\
\hline Correct quantity of supply & $0=\mathrm{No} ; 1=$ Yes & $\begin{array}{l}\text { - (negative) when the suppliers are } \\
\text { unable to maintain the supply } \\
\text { quantity, the greater the likelihood } \\
\text { of plural forms use. }\end{array}$ \\
\hline Transaction frequency & $\begin{array}{l}1=\text { at least once a week; } 2=\text { twice a }- \text { (negative) when the frequency of } \\
\text { week; } 3=\text { three times a week; } 4=\text { transactions is lower, a plural form } \\
\text { four times a week; } 5=\text { five times a } \\
\text { week or more }\end{array}$ & $\begin{array}{l}\text { would be more likely to be used. } \\
0=\text { No; } 1=\text { Yes }\end{array}$ \\
\hline Market price paid & $\begin{array}{l}\text { goods is equal to the market price, } \\
\text { then the probability of plural forms } \\
\text { use decreases. }\end{array}$ \\
\hline
\end{tabular}

Note. Source: Created by the author of this study.

A correlation matrix of the variables was performed, aiming to verifying multicollinearity. The matrix presented no correlation between the variables. Therefore, the model does not exhibit multicollinearity problem.

A waste examination was accomplished to verify if the model has a specification problem; in other words, whether any relevant variable was omitted. Thus, it could be assumed that the model was without any specification mistakes due to the systematic standard absence in the waste graph.

\section{Importance of Ceasa}

In the early 1970s, the commercialization of horticultural products was difficult, mainly due to the precariousness of the equipment used, lack of adequate physical space for its commercialization and the absence of regulations for this sector. As a result, the Federal Government started to be concerned with the horticultural products supply in the country. Therefore, the Government created the first National Development Plan by Law n 5.7272 of 1971, and regulated the National System of Supply Centers (SINAC) by Decree n 70.502 of 1972 (Brazilian Association of Supply Centers [Associação Brasileira das Centrais de Abastecimento - ABRACEN], 2013).

This plan's principal priority was the construction of 21 companies denominated Central Supply (Ceasa), which would generate benefits for both final consumers and entire production chains. This goal was achieved by assisting the sector with market information, empowering agents, improving standardization, and classifying products. In addition, Cease has played a fundamental role in improving both packaging and pesticide control (ABRACEN, 2013).

After the physical construction stage, Sinac began the process of improving marketing channels of horticultural products. This enhancement resulted in a diversification of the products offered, innovative eating habits acquired by the population and the emergence of new frontiers in horticultural production, which have contributed to supply regularity, product quality, and product cost reduction (ABRACEN, 2013).

At the end of 1986, the Federal Government passed control of Ceasas to states and cities. Thus, Ceasas are currently dealing with several issues, such as lack of large investments in structural and service facilities. This signifies that these organizations must play a new role, such as interacting and formalizing partnerships with every sector participating in the agribusiness supply chain, and linking final distributions system expectations with consumer demands. (Ministry of Agriculture, Livestock and Supply [Ministério da Agricultura, Pecuária e Abastecimento - MAPA], 2012). 
This new position led to quality management, with Ceasas able to facilitate its projects' operationalization. The objective was to modernize its space, diversifying and expanding goods supply and services quality as expected by consumers (MAPA, 2012).

The increase in contaminations occurrence and poor quality of the marketed fruits and vegetable have augmented consumer concern with product quality, pressuring Ceasas to assume an essential role where a favorable modernization of production and marketing is feasible (ABRACEN, 2013).

Ceasa-MS is located in the city of Campo Grande, the capital of Mato Grosso do Sul state. This market had its beginnings in 1979 and during this period, its space and organization was limited to merely two pavilions: A and B. However, it officially started operations only in 1983. In the beginning, Ceasa was intended to be a trade-center for local farmers, where they could sell their produce directly to the consumers. However, during that period, limited farmers were involved with this process, which attracted some wholesalers to start doing business at the Ceasa as well (Ceasa-MS, 2007).

\section{Results and Discussions}

\section{Characterization of contractors}

The majority of products marketed by contractors, in Ceasa-MS, are fruits and vegetables. The contractors have a range of producers with whom they trade, $83.33 \%$ of them deal with more than 5 producers and $8.99 \%$ of them trade with no producers. These $8.99 \%$ are producers who do not buy goods from other farmers due to their potential to sell their entire production, i.e. they trade via vertical integration.

The principal states where the goods acquired by Ceasa-MS come from are: São Paulo, Mato Grosso do Sul, Minas Gerais, Paraná, Santa Catarina, Goiás, Bahia, Rio Grande do Sul, Rio Grande do Norte, Espírito Santo, Tocantins, Mato Grosso and Rondônia. Some contractors want to differentiate themselves; therefore, they import products from other countries, such as Spain, Chile and Argentina.

The contractors carefully choose relationships with producers based on crucial characteristics, such as product quality, price, supply stability, friendship with the farmer, farmer location, and a history of buying from the same producer.

Regarding product perishability, decisive maintenance is carried out when they are purchased. It is noteworthy that the frequency in which most of these consumers buy their products is 5 times a week or even more.

Certain transactions implemented by the contractors either moves directly toward the producers, or the contractor hires intermediaries who buy the goods from the producer and directs them to the contractors, charging a markup on the products.

\section{Organizational forms}

The TCE argues that the governance structures are determined by the transaction attributes, such as the frequency with which the transactions are performed and the asset specificity (Williamson, 1996).

Accordingly, in order to determine which organizational arrangement the contractors use, three transaction attributes were analyzed and consequently defined to establish whether the transactions comply with the proposed approach. 


\section{Transaction Dimensions}

According to Williamson (2005) asset specificity represents the main explanatory aspect of the theory, referring to the degree to which alternative users can reapply an asset in alternative forms without resulting in loss of value.

It can be said that the products sold by the contractors at Ceasa-MS presented an average specificity, as observed in Table 4, since there was no need for specific investments in neither transportation nor delivery of such products. Nevertheless, this asset had a major seasonal specificity due to their highly perishable nature if not sold within the correct time frame, which could generate a significant loss of product value and even financial loss to the company.

Table 4

Specificity Performance of Agri-food Products at Ceasa-MS, 2015

\begin{tabular}{ll}
\hline Specificity Type & Degree \\
\hline - Local specificity & $\begin{array}{l}\text { Average, because the origin of certain products influences their quality. Thus, } \\
\text { when the contractor does not buy the product from certain regions in the country, } \\
\text { he/she cannot find the same product in any other regions. There are certain } \\
\text { products, which do not have qualities directly tied to the region from which they } \\
\text { come from. }\end{array}$ \\
\hline - Physical specificity & $\begin{array}{l}\text { Low, since there is no need for specific investments in machinery or equipment } \\
\text { for the transaction. }\end{array}$ \\
\hline - Human specificity & $\begin{array}{l}\text { Low, since there is no need for investments in personnel with specific skills } \\
\text { regarding the handling of agri-food products. }\end{array}$ \\
\hline - Dedicated asset & $\begin{array}{l}\text { Average, since the products' origin is important. However, the products' } \\
\text { transportation requires no specific investments. }\end{array}$ \\
\hline - Seasonal specificity & $\begin{array}{l}\text { Elevated, since the products are highly perishable if not sold within the correct } \\
\text { period, which could generate a significant decrease in the products' value. }\end{array}$ \\
\hline
\end{tabular}

Note. Source: Research results.

Uncertainty is represented as the main cause of disturbances that companies need to adapt to (Williamson, 2005) and this variable can be considered significantly elevated in transactions between farmers and contractors. Although the majority of farmers can keep up with the demand for constant high-quality production even when there are unexpected alterations, more than half of the contractors $(60.56 \%)$ reported some breach in the transactions caused by the farmers. In addition, the product is seasonal and highly dependent on favorable weather conditions.

The third dimension highlighted is the frequency in which transactions are performed, and its relevance in two aspects: the effect of reputation among the parties and the costs to process internalization (Williamson, 2005). The transaction frequency between farmers and contractors varies from 2 to 5 times a week. This research elucidated that as the transaction frequency between farmers and contractors increased, transactions costs started to diminish.

Approximately half of the transactions occur at least 5 times a week, resulting in an increased sense of trust and confidence between farmers and contractors. This leads to a higher complicity between them and a desire to fulfill promises, which in turn results in a good reputation conception and recognition among the parties. Therefore, transaction costs tend to decrease.

\section{. TCE and Plural Forms}

According to Williamson's theory (2005), the transactions can occur in three different manners: classic market activity (a simple trade at a spot market), hybrid contracts or hierarchy. 
According to the theory, after recognizing how transactions dimensions between producers and contractors of Cease-MS work, it was possible to observe that transactions should exist in hybrid forms, i.e. utilizing contracts. For instance, where the asset specificity worked as average, the uncertainty presence was elevated and the transactions frequency was consistent.

Nevertheless, the argument proposed by the theory was not compatible with the reality observed. The transactions analyzed occurred under several different organizational forms. The structures perceived were: hybrid forms, vertical integration and plural forms. It was well-defined that certain contractors supply themselves by means of vertical integration and hybrid forms.

According to Williamson (2005), hybrid forms are characterized by both products purchased directly from the farmer and the price paid following the current market price at the time of the final deal. Since in most cases the relationships have existed for a longstanding period, there is a mutual dependency generated between farmers and contractors. The use of informal and formal contracts was also observed as precaution mechanisms against future breaches in transactions. In addition, trade was not anonymously performed, as in the market, instead the farmer knows the contractor in a personal level. Friendships are commonly found between parties.

The next structure observed in the transactions was vertical integration. This structure doesn't appear to be the most efficient in reducing transaction costs, as the theory suggests.

This organizational form should occur when the asset specificity is preeminent, as stated by Williamson (2005). In addition, he points out that difficult is usually found by a company intending to acquire the asset from different locations. However, it was possible to verify that some contractors negotiate exclusively what they produce; for example, there was a lettuce stand where the contractor only sells the lettuce cultivated by himself. This resulted from the contractor's desire to protect himself against uncertainties in their offerings, the product quality of other farmers, and the fluctuation in current market prices. There is also the fact that the contractor might consider his production costs inferior in comparison to the costs of buying from other farmers.

The next studied structure is not found in Williamson (2005), but is approached by other authors such as Ménard (2013), Mols (2010), and Parmigiani (2007). This structure can be classified among the plural forms of governance, in which the contractors use two or more organization forms simultaneously for the same asset.

The plural forms observed among some of the contractors at Ceasa-MS were the combination of the hybrid form with vertical integration. Some products are purchased directly from the farmers, a transaction that allows for the contractor to pay the current market price. In this instance, the contractor knows the farmer and transactions are not performed anonymously, but through the use of formal and informal contracts. Using the hybrid forms, the contractors can protect assets as well as acquire the advantage of increasing or reducing the supply according to product demand.

Contractors also produce their own merchandise. Using vertical integration, the contractor possesses a fixed amount of product for sale and can keep up a standard of quality required from farmers in each purchase of products.

For a more in-depth result, in relation to the variables that can influence the use of plural forms, we used a Logit model, displayed in Table 5. 
Table 5

\section{Logit Model}

\begin{tabular}{ll}
\hline Variables & Logit Model \\
\hline Constant & 5.27161 \\
& $(0.125)$ \\
\hline Number of suppliers & -0.9365603 \\
& $(0.016) * *$ \\
\hline Sell all products & -0.3059894 \\
& $(0.689)$ \\
\hline Transaction break & 1.007868 \\
\hline Time of operation & $(0.182)$ \\
\hline Quality of supply & $-0.4203768 *$ \\
& $(0.090)$ \\
\hline Quantity of supply & 0.000571 \\
& $(1.00)$ \\
\hline Transactions frequency & -0.6944833 \\
& $(0.316)$ \\
\hline Market price & -0.1474166 \\
\hline Count R & $(0.626)$ \\
\hline
\end{tabular}

Note. Source: Research results.

According to the Logit model, we noticed that the operation period and the quantity of suppliers were the variables that statistically explained plural forms adoption. They were negatively related to plural forms; in other words, when the company was beginning and the number of producers was inferior, the greater was the likelihood of adopting plural forms utilization. In general, the model correctly predicted $75.86 \%$ of the observations (count $\mathrm{R}^{2}=0.7586$ ).

Company age may be related to ambiguity and complexity, factors that Ménard (2013) cited as possible determinants of plural forms use. Therefore, regarding the briefer time, contractors may not be able to measure the asset accurately, which would result in difficulties in choosing the correct governance structure, hence the need of using plural forms. This occurrence was correlated with ambiguity, as mentioned by Ménard (2013).

Attributable to the larger number of transactions that the contractors perform, their monitoring is complex, requiring a pronounced experience for better management. Therefore, the younger the company, greater use of plural forms would be due to the noticeable inexperience of contractors in monitoring the complex transactions performed by them. This factor could be related to the complexity in monitoring transaction alluded to by Ménard (2013).

It was expected that when the quantity of contractors' suppliers was more elevated, the greater the probability of using plural forms due to the eminent complexity in monitoring transactions, but this was not observed. 


\section{- Governing Structures}

Considering the three governing structures, market, hybrid forms and vertical integration, proposed by Williamson (2002). Table 6 makes a connection between the degree of attributes found in the transactions with the best organizational arrangement that protects the asset and reduces transaction uncertainties.

In conclusion, the best governing structure under the light of the transaction dimensions is the hybrid form. Utilizing hybrid forms, contractors could protect their assets, which denote an average specificity, by the use of contracts. Transaction costs were reduced through the excellent reputations generated between contractors and farmers at Ceasa-MS - Table 6.

Table 6

Transaction Dimensions and the Use of Hybrid Forms at Ceasa-MS, 2015

\begin{tabular}{|c|c|c|}
\hline Transaction Attributes & Degree of attributes & Governance structure \\
\hline Asset specificity & $\begin{array}{l}\text { It displays an average specificity since the } \\
\text { product sold was easily found either in other } \\
\text { locations or from other farmers. However, } \\
\text { these products also display elevated } \\
\text { seasonal specificity since they are highly } \\
\text { perishable and both production and } \\
\text { consumption are extremely seasonal. }\end{array}$ & \multirow[t]{3}{*}{$\begin{array}{l}\text { Hybrid forms were the most } \\
\text { adequate governance structure due to } \\
\text { the potential of being adapted to the } \\
\text { behavior attributes of transaction. }\end{array}$} \\
\hline Frequency & $\begin{array}{l}\text { It displays a preeminent frequency of } \\
\text { transactions since the production is } \\
\text { perishable and it is necessary to purchase } \\
\text { the product as well as supply it regularly. In } \\
\text { this manner, there was always a transaction } \\
\text { consistency, creating deeper trust and } \\
\text { confidence between the parties and } \\
\text { encouraging both to fulfill promises, since } \\
\text { their reputation was involved. }\end{array}$ & \\
\hline Uncertainty & $\begin{array}{l}\text { The uncertainty presented in transactions } \\
\text { between farmers and contractors was } \\
\text { elevated. There are several reported cases of } \\
\text { breaches in transactions performed by } \\
\text { farmers. There was also supply uncertainty } \\
\text { and product's quality hesitation especially } \\
\text { because of agri-food dependence on weather } \\
\text { conditions, demand and seasonal } \\
\text { consumption. }\end{array}$ & \\
\hline
\end{tabular}

Note. Source: Research results.

Table 6 suggests that the best option for the contractors at Ceasa-MS regarding governance structure to reduce transaction costs are the hybrid forms. However, it is important to highlight that the hybrid form use does not protect the users from uncertainty and unpredictability of supply and demand.

Table 7 demonstrates that transactions performed under plural forms of governance have enabled contractors to avoid the weak points affecting the transaction success, when such transactions were performed under merely one form of governance structure. This emphasizes the concept that plural forms represent organizational forms that generate the best combination of benefits between hybrid forms and vertical integration. Hence, the incentives intensity, the autonomy and the contractual legislation were found in a semi-strong form, as they were the positive purposes of hybrid forms. The administrative controls and coordination among parties were classified as strong forms due to their positive points of vertical integration. 
Table 7

Different Attributes of the Plural Forms at Ceasa-MS

Governing Structure

Plural Form (Vertical integration and hybrid forms)

\begin{tabular}{ll}
\hline Competencies & \\
\hline Incentives & Semi-strong \\
\hline Administrative controls & Strong \\
\hline Autonomy & Semi-strong \\
\hline Cooperation & Strong \\
\hline Contractual Legislation & Semi-strong \\
\hline
\end{tabular}

Note. Source: Research Results.

Consequently, the organizational arrangement resulting in the lowest transaction costs for the contractors were actually the plural forms. The use of hybrid forms simultaneously with vertical integration led to asset protection, and the adaptation of products sold by the contractors, which were performed more rapidly as the demand and quality were more consistent. In addition, the plural forms allowed for the strong association of hybrid forms with vertical integration, canceling out the eventual weaknesses present in both governance structures when used individually.

\section{Conclusion}

In conclusion, the transactional aspects of the relationship between farmers and contractors at Ceasa-MS could be analyzed regarding the contributions made by Williamson (2005) and by the plural forms.

The asset analyzed in this study was horticultural products, a property with an average specificity attributable to the lack of necessity of specific investments for transportation or delivery for such products. However, these assets display an extremely elevated seasonal specificity, because of their dependence on seasonal crops and weather conditions. In addition, when these were not consumed within the right period, there could be serious loss of value to the product as well. The uncertainties around a transaction were preeminent and related to quantity and quality. Nevertheless, since the transactions occur with high frequency and show consistency, there would exist the establishment of reputations among farmers and contractors, which contribute to less breaching of agreements between them.

According Williamson's theory, the transactions that were analyzed in Ceasa-MS must occur through hybrid forms. In others words, contractual forms is the governance structure that present inferior transaction costs. Conversely, this study has acknowledged that besides the hybrid forms, the transactions were also performed in vertical integration and plural forms, where there was a combination of hybrid forms with vertical integration simultaneously.

Additionally, among the three determining aspects for the use of plural forms as suggested by Ménard (2013), we observed that ambiguity and the complexity in monitoring the transactions are also present in the relationships between farmers and contractors and caused by the company's time of operation. The ambiguity is present because of the difficulties in measuring how specific the asset really is. The transactions' monitoring complexity was due to how uncertainties were related to the complicatedness of monitoring transactions. 
Although the number of suppliers was significant, a positive correlation was expected with plural forms adoption, however, this was not seen.

Therefore, as mentioned before, the organizational arrangement that generates the lowest transaction costs for the contractors is the use of plural forms, which is the combination of hybrid forms with vertical integration. This type of arrangement combines positive points of both governing structures, nullifying the transactions' possible weak points, which would occur when merely one structure was in play.

The study's contribution is essential to demonstrate that the contractors utilizing plural forms to perform their transactions could protect assets using contracts. Moreover, the contractors can keep up with market demand fluctuation by using hybrid forms. By means of vertical integration, the contractors may obtain a standard of product quality and a fixed supply quantity for merchandise sales.

The use of plural forms in Ceasa is statistically related to a company's time of operation. The younger the company, the greater the probability of adopting the use of plural forms.

Research limitations include the lack of information in data collection related to respondents' characteristics, such as the level of education and experience. As the work has a qualitative character, and statistical tools were utilized, the research presented limitations regarding the small number of observations and the non-randomness of observations for the use of Logit. Moreover, for the questionnaires applied, only respondents that used plural forms in their transactions were included to perform the quantitative study. A test of variable endogeneity was not carried out, since they were taken from the theory proposed by Ménard.

These limitations may weaken the statistical part of work. Nevertheless, it should not be forgotten that the work goal was to perform a qualitative analysis. Thus, statistical tools worked only as a complement to this work.

Further studies could be carried out focusing on the analysis of transactions between contractors and their clients, intending to identify whether plural forms of governance also exist in this case and if there are any noticeable advantages for contractors carrying their business forward using such structures.

\section{References}

Associação Brasileira das Centrais de Abastecimento. (2013). Plano nacional de abastecimento: Sob a ótica das centrais de abastecimento do Brasil. Recuperado de http://www.files.ceasace.com.br/pna.pdf

Bradach, J. L., \& Eccels, R. G. (1989). Price, authority, and trust: From ideal types to plural forms [Electronic version], Annual Review of Sociology, 15, 97-118. Retrieved from http://www.annualreviews.org/doi/pdf/10.1146/annurev.so.15.080189.000525\#article-denial. http://dx.doi.org/10.1146/annurev.so.15.080189.000525

Carter, R., \& Hodgson, G. M. (2006). The impact of empirical test of transaction cost economics on the debate on the nature of the firm [Electronic version], Strategic Management Journal, 27(5), 461476. Retrieved from http://www.geoffrey-hodgson.info/user/image/empiricaltesttce.pdf. http://dx.doi.org/10.1002/smj.531

Centrais de Abastecimento de Mato Grosso do Sul. (n.d.). Conheça a Ceasa MS - Estrutura de comercialização. Recuperado de http://www.ceasa.ms.gov.br/conheca-a-ceasa-ms/

Centrais de Abastecimento de Mato Grosso do Sul. (2007). Conheça a Ceasa. Recuperado de http://www.ceasa.ms.gov.br/empresa.html 
Chen, C. C., Peng, M. W., \& Saparito, P. A. (2002). Individualism, collectivism, and opportunism: A cultural perspective on transaction cost economics [Electronic version], Journal of Management, 28(4), 567-583. $\quad$ Retrieved from http://citeseerx.ist.psu.edu/viewdoc/download?doi=10.1.1.195.4557\&rep=rep1\&type=pdf. http://dx.doi.org/10.1177/014920630202800405

Cliquet, G., \& Croizean, J. P. (2002). Towards plural forms, franchising/company-owned systems, in the French cosmetics retail industry [Electronic version], International Journal of Retail \& Distribution Management, 30(5), 238-250. Retrieved from http://www-emeraldinsightcom.ez51.periodicos.capes.gov.br/doi/pdfplus/10.1108/09590550210426408. http://dx.doi.org/10.1108/09590550210426408

Coase, R. H. (1937). The nature of the firm [Electronic version], Economica, 4(16), 386-405. Retrieved from http://www.colorado.edu/ibs/es/alston/econ4504/readings/The\%20Nature\%20of\%20the\%20Fir m\%20by\%20Coase.pdf. http://dx.doi.org/10.1111/j.1468-0335.1937.tb00002.x

David, R., \& Han, S.-K. (2004). A systematic assessment of the empirical support for transaction cost economics. Strategic Management Journal, 25(1), 39-58. Retrieved from https://www.mcgill.ca/desautels/files/desautels/david-han-strategic-management-journal2004_0.pdf. http://dx.doi.org/10.1002/smj.359

Eisenhardt, K. M. (1989). Building theories from case study research [Electronic version], The Academy of Management Review, 14(4), 532-550. Retrieved from http://links.jstor.org/sici?sici=03637425\%28198910\%2914\%3A4\%3C532\%3ABTFCSR\%3E2.0.CO\%3B2-R. http://dx.doi.org/10.5465/AMR.1989.4308385

Feltre, C., \& Paulillo, L. F. (2013). A pluralidade nas transações de cana-de-açúcar no oeste paulista [Versão eletrônica], Revista de Administração Comtemporânea, 17(6), 661-678. Recuperado de http://www.scielo.br/scielo.php?script=sci_arttext\&pid=S1415-65552013000600003. http://dx.doi.org/10.1590/S1415-65552013000600003

Foscaches, C. A. L., Saes, M. S. M., \& Vacari, G. F. J. (2016). Formas plurais na aquisição da matériaprima: Uma análise do setor de torrefação e moagem de café no Brasil [Versão eletrônica], Organizações \& Sociedade, 23(78), 507-520. Recuperado de https://portalseer.ufba.br/index.php/revistaoes/article/download/13674/11176. http://dx.doi.org/10.1590/1984-9230788

Foss, N. J. (2003). Bounded rationality in the economics of organization: "Much cited and litthe used" [Electronic version], Journal of Economic Psychology, 24(2), 245-264. Retrieved from http://www-sciencedirect-

com.ez51.periodicos.capes.gov.br/science/article/pii/S0167487002002064. http://dx.doi.org/10.1016/S0167-4870(02)00206-4

Foss, N. J., \& Weber, L. (2016). Moving opportunism to the back seat: Bounded rationality, costly conflict, and hierarchical forms [Electronic version], Academy of Management Review, 41(1), 6179. Retrieved from http://amr.aom.org/content/41/1/61.abstract. http://dx.doi.org/10.5465/amr.2014.0105

Greene, W. H. (2012). Econometric analysis. Ney York: Pearson.

Hair, J. F., Jr., Anderson, R. E., Tatham, R. L., \& Black, W. C. (2009) Análise multivariada de dados. Porto Alegre: Bookman.

Krzeminska, A., Hoetker, G., \& Mellewigt, T. (2013). Reconceptualizing plural sourcing [Electronic version], Strategic Management Journal, 34(13), 1614-1627. Retrieved from 
https://www.researchgate.net/publication/235949562_Reconceptualizing_plural_sourcing. http://dx.doi.org/ 10.1002/smj.2062

Leiblein, M. J. (2003). The choice of organizational governance form and performance: Predictions from transaction cost, resource-based, and real options theories [Electronic version], Journal of Management, 29(6), 937-961. Retrieved from http://ac-els-cdncom.ez51.periodicos.capes.gov.br/S0149206303000850/1-s2.0-S0149206303000850main.pdf?_tid=95c7f912-07c9-11e7-beca00000aab0f6c\&acdnat=1489394984_a9fec2b3ca07f08f3592d0b8d5c9cddf. http://dx.doi.org/10.1016/S0149-2063(03)00085-0

Lourenzani, A. E., \& Silva, A. L. (2004). Custos de transação na distribuição de tomate in natura [Versão eletrônica], Agricultura em São Paulo, 51(1), 41-50. Recuperado de http://www.iea.sp.gov.br/out/publicacoes/pdf/asp-1-04-3.pdf

Macher, J. T., \& Richman, B. D. (2008). Transaction cost economics: An assessment of empirical research in the social sciences [Electronic version], Business and Politics, 10(1), 1-63. http://dx.doi.org/10.2202/1469-3569.1210

Ménard, C. (2004). The economics of hybrid organizations [Electronic version], Journal of Institutional and Theoretical Economics, 160(3), 345-376. Retrieved from http://www.dse.univr.it/documenti/OccorrenzaIns/matdid/matdid425733.pdf. http://dx.doi.org/10.1628/0932456041960605

Ménard, C. (2013). Plural forms of organization: Where do we stand [Electronic version], Managerial and Decision Economics, 34(3/5), 124-139. Retrieved from http://onlinelibrary.wiley.com/doi/10.1002/mde.2578/abstract. http://dx.doi.org/10.1002/mde.2578

Ministério da Agricultura, Pecuária e Abastecimento. (2012). Plano de modernização das Centrais de Abastecimento. Recuperado de http://www.abracen.org.br/wp-content/uploads/2013/11/PNA2013-ultima-versao-Newton-e-Pechetoll-1-_5_-_1_.pdf

Mols, N. P. (2010). Economic explanations for concurrent sourcing [Electronic version], Journal of Purchasing \& Supply Management, 16(1), 61-69. Retrieved from http://www.sciencedirect.com/science/article/pii/S1478409209000624. http://dx.doi.org/10.1016/j.pursup.2009.09.001

Mondelli, M., \& Zylbersztajn, D. (2008). Determinantes dos arranjos contratuais: O caso da transação produtor-processador de carne bovina no Uruguai [Versão eletrônica], Revista de Economia e Sociologia Rural, 46(3), 831-868. Recuperado de http://www.scielo.br/scielo.php?script=sci_arttext\&pid=S0103-20032008000300010. http://dx.doi.org/10.1590/S0103-20032008000300010

Parmigiani, A. (2007). Why do firms both make and buy? An investigation of concurrent sourcing [Electronic version], Strategic Management Journal, 28(3), 285-311. Retrieved from http://www.business.illinois.edu/josephm/BA549_Fall\%202014/Session\%203/3_Parmigiani\%2 0(2007).pdf. http://dx.doi.org/10.1002/smj.580

Poppo, L., \& Zenger, T. (2002). Do formal contracts and relational governance function as substitutes or complements? [Electronic version], Strategic Management Journal, 23(8), 707-725. Retrieved from http://www.toddzenger.com/wp-content/uploads/2015/08/FormalContracts.pdf. http://dx.doi.org/10.1002/smj.249

Silveira, R. L. F., Carrer, M. J., Carvalho, T. B., Foscaches, C. A. L., \& Saes, M. S. M. (2014). Formas plurais de governança: Uma análise das transações de suprimento entre frigoríficos e pecuaristas [Versão eletrônica], Revista de Economia e Sociologia Rural, 52(4), 761-782. Recuperado de

RAC, Rio de Janeiro, v. 21, n. 6, art. 1, pp. 743-763, Novembro/Dezembro, 2017, www.anpad.org.br/rac (cc) EY 
http://www.scielo.br/scielo.php?script=sci_arttext\&pid=S0103-20032014000400008. http://dx.doi.org/10.1590/S0103-20032014000400008

Silvia, C. L., \& Saes, M. S. (2005). A questão da coexistência de estrutura de governança na economia dos custos de transação: Evidências empíricas na avicultura de corte paranaense. Revista de Administração Mackenzie, 6(3), 88-118. Recuperado de http://www.redalyc.org/articulo.oa?id=195416195005

Soares, S. S., \& Saes, M. S. (2015). Distribuição de combustível no estado de São Paulo: Estruturas de governança e mecanismos complementares de coordenação [Versão eletrônica]. Revista de Administração, 50(2), 241-253. Recuperado de http://www.scielo.br/pdf/rausp/v50n2/00802107-rausp-50-02-0241.pdf. http://dx.doi.org/10.5700/rausp1197

Speklé, R. (2001). Explaining management control structure variety: A transaction cost economics perspective [Electronic version], Accounting Organizations and Society, 26(4), 419-441. Retrieved from http://isiarticles.com/bundles/Article/pre/pdf/19377.pdf. http://dx.doi.org/10.1016/S0361-3682(00)00041-6

Van Gelder, M. M. H. J., Bretveld, R. W., \& Roeleveld, N. (2010). Web-based questionnaires: The future in epidemiology? [Electronic version], American Journal of Epidemiology, 172(11), 12921298. Retrieved from https://www.ncbi.nlm.nih.gov/pubmed/20880962. https://dx.doi.org/10.1093/aje/kwq291

Williamson, O. (1985). The economic institutions of capitalism. New York: Free Press.

Williamson, O. (1996). The mechanisms of governance. New York: Oxford University Press.

Williamson, O. (2000). The new institutional economics: Taking stock, looking ahead [Electronic version], Journal of Economic Literature, 38(3), 595-613. Retrieved from https://www.jstor.org/stable/2565421?seq=1\#page_scan_tab_contents.

http://dx.doi.org/10.1257/jel.38.3.595

Williamson, O. (2002). The theory of the firm as governance structure: from choice to contract [Electronic version], Journal of Economic Perspective, 16(3), 171-195. Retrieved from http://kisi.deu.edu.tr/sedef.akgungor/Williamson.pdf.

http://dx.doi.org/10.1257/089533002760278776

Williamson, O. (2005). The economics of governance [Electronic version], American Economics Review, 95(2), 1-18. Retrieved from http://www-jstororg.ez51.periodicos.capes.gov.br/stable/pdf/4132783.pdf. http://dx.doi.org/10.1257/000282805774669880

Williamson, O. (2008). Outsourcing: Transaction cost economics and supply chain management [Electronic version], Journal of Supply Chain Management, 44(2), 5-16. http://dx.doi.org/10.1111/j.1745-493X.2008.00051.x

Yin, R. K. (1981). The case study crisis: Some answers [Electronic version], Administrative Science Quarterly, 26(1), 58-65. Retrieved from http://links.jstor.org/sici?sici=00018392\%28198103\%2926\%3A1\%3C58\%3ATCSCSA\%3E2.0.CO\%3B2-H.

http://dx.doi.org/10.2307/2392599 


\section{Authors' Profiles}

Susan Yuko Higashi

Av. Senador Filinto Müller, 1555, Vila Ipiranga, 79074-460, Campo Grande, MS, Brasil. E-mail address: susan_yuko@hotmail.com

Mayra Batista Bitencourt Fagundes

Av. Senador Filinto Müller, 1555, Vila Ipiranga, 79074-460, Campo Grande, MS, Brasil. E-mail address: bitencourtmayra@gmail.com

Silvia Morales de Queiroz Caleman

Av. Senador Filinto Müller, 1555, Vila Ipiranga, 79074-460, Campo Grande, MS, Brasil. E-mail address: silviacaleman@gmail.com

Leandro Sauer

Av. Senador Filinto Müller, 1555, Vila Ipiranga, 79074-460, Campo Grande, MS, Brasil. E-mail address: leandrosauer@uol.com.br

Maria Sylvia Saes

Av. Prof. Luciano Gualberto, 908, Butantã, 05508-900, São Paulo, SP, Brasil. E-mail address: ssaes@usp.br, sylviasaes@gmail.com 